\title{
Terrorism as a form of Imperialism: A Case for the Rule of Law
}

\author{
Brian Kimari *
}

\begin{abstract}
The war on terror is indeed justified. Terror attacks have resulted in the deaths of many innocent people around the world. Every nation in fact has a duty to protect her citizens from terror attacks and put up measures to prevent and punish terrorists. However, the government also has a duty to uphold the rule of law at all times despite the gravity of the attacks. This paper disputes arguments that terrorism is so novel and so grave that the rule of law can be sacrificed in order to deal with it. This position fails since terrorism is not a novel challenge and further because terrorism manifests itself as a form of imperialism, which is a challenge that has several times been dealt with in world history. Terrorism does not change the normal rules of criminal procedure and thus the rule of law should not be suspended in the name of counter-terrorism.
\end{abstract}

\section{Introduction}

Recently, Kenya has withstood the worst of terrorist attacks by the AlShabaab militia group. The major attacks ${ }^{1}$ include the Westgate mall attack ${ }^{2}$

* The author is a student at the Strathmore University Law School in Nairobi, Kenya.

1 Yongo differentiates between major and minor attacks through not only the way that public opinion has treated the attacks. He identifies the major terrorist attacks as follows: the $21^{\text {st }}$ September 2013 attack on the Westgate Mall, the $15^{\text {th }}$ June 2014 attack in Mpeketoni, the $23^{\text {rd }}$ November 2014 bus attack near Mandera, the $2^{\text {nd }}$ December 2014 quarry attack in Koromey, Mandera and the $2^{\text {nd }}$ April 2015 attack on Garissa University College, Garissa.

See Cecil Yongo, The temptation of power in the war against terrorism' Strathmore Annual Law Conference, Nairobi, (4 $4^{\text {th }}$ August 2015), 4, 7.

2 Kenya National Assembly, Report of the Joint Committee on Administration and National

Security, Defence and Foreign Relations on the inquiry into the Westgate terrorist attack, and other terror attacks in Mandera (Northeastern) and Kilifi (Coastal), Nairobi, Kenya National Assembly, 11th Parliament, 1st Session, December 2013.

See also 'Westgate mall attacks' The Guardian, 21 September 2013 http://www.theguardian.com/ world/westgate-mall-attacks on $16^{\text {th }}$ August 2015. 
where Al-Shabaab militants attacked a mall in Nairobi claiming the lives of sixty five civilians and injured seventy five, ${ }^{3}$ the Garissa University attack where AlShabaab militants claimed the lives of at least one hundred and forty seven civilians- mostly students of the university, and injured at least eighty one, and the Mpeketoni attack ${ }^{4}$ on June $15^{\text {th }} 2014$.

These and other attacks have had economic, social, and political effects on Kenya and its people(s). The cost of the war on terror has been costly and has had significant economic implications. ${ }^{5}$ Both the 2014/2015 budget $^{6}$ and 2015/2016 budget $^{7}$ prioritised tackling insecurity.

Terrorism has also had social effects in Kenya with numerous reports of human rights violations. For instance, the 'Operation Usalama Watch' was questioned for its discriminatory and profiling nature and human rights violations, ${ }^{8}$ with some wondering how the two approaches would 'suddenly' make Kenya a

3 'Kenyan mall attacked by gunmen: 67 people reported dead' WABC TV News, 21 September 2013. http://7online.com/ on 1 August 2015.

Gartenstein-Ross D and Appel H, 'Al-Shabaab's insurgency in Somalia: A databased snapshot' Georgetown Journal of International Affairs, 3 April 2014 http:/ journal.georgetown.edu/2014/04/03/ al-shabaabs-insurgency-in-somalia-a-data-based-snapshot-bydaveed-gartenstein-ross-henry-appel/ on $16^{\text {th }}$ July 2015.

4 'Mpeketoni attacks death toll rises to 48' The Daily Nation, 16 June 2014 http://www.nation.co.ke/ news/mpeketoni-Lamu-gunfire-al-shabaab-terrorism/-/1056/2349860/-/yf5qvgz/-/ on 21 July 2015.

5 Operation Linda Nchi is estimated to have cost the government at least Ksh. 210 million per month in 2011. See 'Kenya shifts cost of Somalia war to the United Nations,' Business Daily, 7 December 2011.

http://www.businessdailyafrica.com/Corporate-News/Kenya-shifts-cost-of-Somalia-war-to-theUnited-Nations-/-/539550/1285812/-/4wkycg/-/index.html on 10 December 2015.

6 The Treasury allocated Ksh 66.2 billion for the National Police Service, Ksh. 71.3 billion for Kenya Defence Forces and Ksh17.4 billion for National Security Intelligence.

See 'Which sectors bagged larger share of Kenya's trillion budget' Awake Africa, June 132014 http:/ / awakeafrica.org/which-sectors-bagged-larger-share-of-kenyas-trillion-budget/ on 5 September 2015.

7 Sh $223 \mathrm{bn}$ for security services (an increase of Sh27bn) Sh 112.5bn for military security and Sh102bn for internal security. This includes Sh 25bn allocated to security modernisation (police and military), Sh. 6.4bn for AMISOM, and Sh. 7.7bn for leasing vehicles.

See 'Budget analysis: Some 34 items included in 2015/16 budget that affects you' Kenya Today, 2015 http://www.kenya-today.com/business/budget-analysis-34-items-included-201516-budget-affects on 5 September 2015.

See also Parliamentary Budget Office, Unpacking the budget policy statement, 2015/16, and the Medium Term, 2015.

$8 \quad$ Human Rights Watch, World Report 2015: Events of 2014, 2015, 331.

It is reported that during Operation Usalama Watch in Nairobi and Mombasa in April, security officers from multiple agencies raided homes, buildings, and shops, carting away money, cell phones, and other goods. They harassed and detained thousands - including journalists, refugees, Kenyan citizens, and international aid workers - without charge, and in appalling conditions for periods well beyond the 24-hour legal limit. 
more secure country. ${ }^{9}$ Further, there have been reports of arbitrary detention, ${ }^{10}$ torture, disappearance, and extra-judicial killings of terrorism suspects, Somali refugees and other people of Somali origin by security forces. ${ }^{11}$ Treatment of this sort risks alienating Somalis and may lead to resentment for the Kenyan government and its security forces, which may in turncontribute to the risk of recruitment into Al-Shabaab and an increase in the number of Al-Shabaab sympathisers because of such resentment. ${ }^{12}$

The manner in which the security agencies have carried out the war on terror in Kenya is bound to have political effects. The targeting of the Somali Community, ${ }^{13}$ for instance, is bound to have political effects due to the large number of Kenyan Somalis ${ }^{14}$ and Somali refugees ${ }^{15}$ living in Kenya. Kenya's attempts to create a buffer zone between the border and Somalia privileges the Ogaden community, who form the majority in Kenya, and this might create tension between the Ogaden and the minorities such as the Ajuran and Degodia. ${ }^{16}$ The insecurity issue in Kenya seems to have been further politicised as can be seen through its use in rallying for political support. ${ }^{17}$ It has further been a key point behind the proposed constitutional amendment of $2015^{18}$ where the op-

9 Kenya National Commission on Human Rights, Operation Usalama Watch; Too little too late, 16 May 2014. http://www.knchr.org/OperationUsalamaWatchToolittletoolate.aspx on 1 September 2015.

10 Human Rights Watch, Kenya: Security forces arbitrarily detaining people, 2011.

www.hrw.org/news/2011/11/28/kenya-security-forces-arbitrarily-detaining-people on 1 September 2015.

11 Human Rights Watch, World Report 2015: Events of 2014, 333.

12 'Somalia, Kenya risks death by a thousand cuts', NDU Press, PRISM 3(3), 2012. http://www.ndu. edu/press/somalia-kenyarisks-death.html on 1 September 2015.

13 The late Former Deputy Defence Minister, Orwa Ojode, was captured saying that the Al- Shabaab is a snake with its head in Eastleigh and its tail in Somalia. Eastleigh was clearly a target due to the large Somali population.

See 'War fears: Somalis in Kenya afraid of xenophobia' Associated Press, 11 November 2011.

http://www.boston.com/news/world/africa/Articles/2011/11/11/war_fears_somalis_in_kenya_ afraid_of_xenophobia_1321030186/ on 10 December 2015.

14 As of 2009, there were nearly 2.4 million Kenyan Somalis

See Kenya National Bureau of Statistics, 2009 Population and housing census results, 31 August 2010, www.knbs.or.ke on 23 July 2015.

15 As of 2009, there were almost 500, 000 Somali Refugees.

See UN High Commissioner for Refugees, 2012 UNHCR country operations profile - Kenya, 2012 www. unhcr.org on 26 July 2015.

16 Crisis Group Africa Report N¹84, The Kenyan military intervention in Somalia, 15 February 2012, 13.

17 IPSOS, 'The big divide over Operation Linda Nchi', 1 November 2014. http://www.ipsos.co.ke/NEWBASE_EXPORTS/Political $\% 20$ Parties/141101_The $\% 20 S \operatorname{tar} \% 20$ Siasa\%20Mag._3_896dd.pdf on 5 September 2015.

18 See Article 24, Constitution of Kenya, (2010).

https://odmyouthreloaded20172018.files.wordpress.com/2015/04/the-okoa-kenya-Constitutionalamendment-bill-1.pdf on 5 September 2015. 
position leader Raila Odinga highlighted security as one of the main sectors that require improvement. Adding to the political fold, following the attack in Lamu, President Uhuru Kenyatta expressed his concerns that the terrorist attacks were the product of local politics. ${ }^{19}$ It was not clear whether the president directed the statement at the Coalition for Reforms and Democracy (CORD) leader Raila Odinga, the Mombasa Republican Council (MRC) attempts at secession or political squabbles in Lamu. ${ }^{20}$ What was clear, however, was that the Al-Shabaab played a role in the attack ${ }^{21}$ and that the political divide in Kenya was a strong weapon for the Al-Shabaab. ${ }^{22}$

As illustrated above, terrorism is a major problem and no contrary interpretation should be taken from this paper. The Kenyan government's reaction to terrorism is indeed justified both externally and within its borders. However, such government action and reaction is only justifiable when done within the confines of the rule of law. This paper argues that despite the magnitude of terrorism, the government must still respect the rule of law.

Critics of the rule of law argument, in relation to terrorism, say that terrorism requires the suspension of normal rules. ${ }^{23}$ Some argue that terrorism suspects do not deserve the same guarantees and safeguards that a citizen going through the normal judicial process deserves. ${ }^{24}$ This paper seeks to refute such arguments by showing the importance of the rule of law.

Bremer argues that in spite of the impressions that some people may have, terrorism is nothing new but has been around for centuries. ${ }^{25}$ Concurring with Bremer, this paper puts forward the idea that terrorism and challenges similar to terrorism are not new. 'Challenges similar to terrorism' refers specifically to 'im-

19 'Uhuru blames massacre on tribalism, hate politics' Daily Nation, 17 June 2014. http://www.nation. co.ke/news/Uhuru-blames-massacre-on-tribalism-hatepolitics/-/1056/2352306/-/wyy1laz/-/ index.html on 11 September 2015.

20 'Mpeketoni attacks: four possibilities' BBC News Online, 17 June 2014, http:/ /www.bbc.co.uk/news/ world-africa-27890084 on 7 September 2015.

21 'Westgate, Mpeketoni killings suspects held' The Star, 29 July 2014. http://www.the-star.co.ke/ news/Article-180630/westgate-mpeketoni-killings-suspects-held on 7 September 2015.

22 'Militants' firebomb campaign sows fear in Kenyan resorts' The Guardian, 17 July 2014, http:/ /www. theguardian.com/world/2014/jul/17/militants-firebomb-campaign-sows-fear-in-kenyan-resorts on 31 August 2015.

23 Dickinson L A, 'Using legal process to fight Terrorism: Detentions, Military Commissions, International Tribunals, and the Rule of Law' 75. California Law Review, (2002), 1415.

24 Richey W, 'How long can Guantanamo prisoners be held?' Christian Science Monitor, 9 April 2002. 1, 4.

25 Bremer L P, 'Counterterrorism: Strategy and tactics' committee on Foreign Relations, Tampa Florida, 1 November 1987. (This address has been published by the Bureau of Public Affairs, Department of State, as Current Policy No. 1023). 
perialism.' This paper brings out terrorism as one of the methods of imperialism.

The similarity between imperialism and terrorism is that they both intend to alter the status quo of particular governments or states, the difference largely being in the method by which the change in status quo is approached. This identification is essential to the argument that since forms of imperialism, especially military imperialism, has rules that must be adhered to such as the rules of war and international rules governing state relations and domestic rules governing inter-state relations, states should likewise observe these rules when dealing with terrorism.

This paper will further emphasise the importance of the rule of law when dealing with terrorism, arguing that respecting the rule of law may indeed be a more effective way of dealing with the terrorist menace. Finally, the paper analyses the measures that Kenya has taken in the fight against terrorism and proposes recommendations or reforms to ensure compliance with the rule of law.

\section{II. 'Imperialism' defined}

The term 'imperialism' has been used to describe or explain varied actions and dispositions. For instance, other states viewed the British as imperialistic when they acquired colonies in Africa, ${ }^{26}$ the Soviet's Union policy of communism was viewed to be imperialistic, ${ }^{27}$ and so was Chinese industrial action in Africa. ${ }^{28}$ Moreover, others use the term 'American imperialism' in reference to some actions taken by the United States, whether in industry, military and even culture. $^{29}$

The meaning of the term is as clear as mud. It has been used as a tool against foreign policies, which are opposed by the user of such a term, despite consideration of the actual substance and intention of the policy pursued. ${ }^{30}$ It is

26 Cain P J and Hopkins A G, British Imperialism: Innovation and expansion 1688 - 1914, Longman Publishers, 2000.

Lloyd T O, The British Empire, 1558-1995, Oxford University Press, edition 2, 1966.

27 Velyschenko S, Painting Imperialism and nationalism red: The Ukranian Marxist Critique of Russian Communist Rule in Ukraine, 1918-1925, University of Toronto Press, 3 September 2015.

28 Hitchens P, 'Africa's last, worst hope: A continent that withstood European colonialism welcomes Chinese conquest' The American Conservative Vol 7, No.23, 1 December 2008.

29 Field Jr. J A, 'American imperialism: The worst chapter in almost any book' The American Historical Review Vol. 83, No. 3, June 1978, 644-668.

30 Schumpeter J, The sociology of imperialisms, as reprinted and translated in Imperialism and Social Classes, ed Hoselitz B, New York, Meridian Books, 1955, 11. 
captured as having been 'applied only to the enemy, in a reproachful sense, being carefully avoided with reference to the speaker's own policies. ${ }^{31}$ Langer criticises 'imperialism' as vague, arguing that its use may be extended to cover any form of influence and thus proposes that we stick to a concept that is measurable and manageable. ${ }^{32}$

Despite these and other critiques, it would not be prudent to ignore it completely. Conflict and criticism may be avoidable if the use of the term is limited to a particular definition, which will be the working definition of the writer. As this paper intends on basing its argument on an imperialistic concept, it will rely on a working definition of imperialism.

Since this text focuses on the influence of the relations of foreign unwanted powers and the state, the definition will be only as is relevant to this discussion. It will thus not capture all relations of international politics, facets of colonialism, ${ }^{33}$ neo-colonialism, ${ }^{34}$ theories of imperialism by use of great economic forces, ${ }^{35}$ devil-theory of imperialism ${ }^{36}$ or any other theory that falls outside the scope. ${ }^{37}$

My working definition of imperialism is that it involves a policy devised to overthrow the status quo of the state, that is, a policy that intends to change the relationship between

31 Schumpeter J, The sociology of imperialisms. 11, 71.

32 Langer W, ‘A critique of Imperialism' Foreign Affairs, xiv, 1935, 103.

33 Imperialism is viewed as a valid description of any kind of colonial expansion.

See Moon P T, Imperialism and world politics New York, The Macmillan Company, 1926.

See also Bourguiba H, 'The outlook for Africa', International Affairs, vol. 37, no. 4, 1961, 428.

34 Imperialism is seen as a relationship between the powerful and the powerless, which bestows upon the powerless material consequences and thus grant the powerful control.

See Hourani A, 'The decline of the West in the Middle East' International Affairs, xxix, 1953, 31.

See also Gandhi M, Young India1919-1922, Madras, 1922, 648.

35 Marxists posit that capitalism is the main evil and imperialism is only its necessary manifestation.

See Lenin, Collected Works, New York: International Publishers, Vol XVII, 1929.

See also Lenin, Selected Works, New York: International Publishers, Vol V, 1935.

See also Bukharin, Imperialism, the highest stage of capitalism, New York: International Publishers, 1933, 72.

36 The devil theory views imperialism as a sort of propaganda or conspiracy theory where such policies are seen as having been brought by capitalistic minds in order to obtain economic benefits and become wealthy.

See Beard C, The Devil Theory of War, New York: The Vanguard Press, 1936.

37 A discussion on the different views on imperialism and the various critiques to such views is indeed interesting but is so wide that a completely different paper as a topic on its own would only best capture it. Such an extensive discussion is therefore not important to the idea of this text.

Find a more comprehensive discussion on these matters in Thornton AP, Doctrines of Imperialism, John Wiley and Sons Inc., 1965, 1 - 46.

See also Morgenthau H, Politics among nations: The struggle for power and peace, McGraw Hill Inc., Kenneth W Thompson ed, 1993, $57-65$. 
the rulers and the ruled such that rule of the government of the day is replaced by rule of the designer of the imperialist policy. ${ }^{38}$

\section{Methods of imperialism}

Imperialists have typically employed three methods to achieve their imperialistic objectives. These are military imperialism, cultural imperialism and economic imperialism.

\section{i. $\quad$ Military imperialism}

This kind achieves the goals of imperialism through military conquest. There is an overthrow of the status quo such that the imperialist displaces the rulers from their positions and takes over control of the territories. This is in contrast to economic and cultural forms where imperialism occurs despite rule by the pre-existing instruments of governance.

Several examples of this form of imperialism are seen through the ages, through actual occupation of a territory by another nation or a belligerent government. Military imperialism is understandably more effective since the success of military conquest usually results in immediate victory and allows immediate achievement of the imperialistic goal. ${ }^{39}$ This method, however, carries the greatest risk since should the imperialist be defeated by the holding military, the imperialistic goal is quickly thwarted and further risks occupation by the holding military in countering the imperialist themselves.

38 This definition is based on what I think is the ultimate goal of imperialism which is the domination of those against whom imperialist policy is exercised. Notice that the working definition used does not look at the specific method employed or the content of the said imperialistic policy. This is simply in order to remain objective and allow a policy that is supposedly imperialistic to be judged in by the goals of that policy such that it is imperialistic if it intends to overthrow the government and dominate the people. This is as opposed to giving policies considered to be imperialistic and labelling any similar policies as such.

39 He explains that had Napoleon I used military conquest as opposed to or in addition to using the ideologies of the French Revolution, he would have been able to achieve his imperialistic goals over Europe much faster.

Morgenthau $\mathrm{H}$, Politics among nations, 70. 


\section{ii. Economic Imperialism}

Economic imperialism aims to change the power relations through economic control, rather than exacting control on the actual territory. ${ }^{40}$

There are examples of organized or stronger entities conquering or attempting to conquer weaker or less organized entities for economic ends. For instance, during the scramble and partition of Africa, the more organised European nations sought to acquire colonies or occupy territories in Africa largely for economic purposes. ${ }^{41}$ These states sought to redirect pressure on the resources at home. The idea was simple: acquire resources from Africa and use them at home. $^{42}$

Though the colonial powers saw strategic, dynastic, and sentimental reasons for acquiring colonies, ${ }^{43}$ the economic advantage of colonialism was as a more direct goal of colonialist policies. ${ }^{44}$ Sir Frederick Lugard showed this particular goal of imperialism in this statement: 'I do not believe that in these days our national policy is based on motives of philanthropy only. 45

\section{iii. Cultural Imperialism}

This form of imperialism comprises all kinds of intellectual influences, political and otherwise that serve as means for imperialistic ends. It aims at the control or possible manipulation of the minds or thought process of the people in order to change existing power relations. It is seen as a means through which weaker entities are attracted, pressured, forced, and sometimes bribed into shaping their social institutions to correspond to, or even promote, the values and structures of the imperialistic or dominant actor. ${ }^{46}$

In this, a culture is made to appear superior or an attractive political philos-

\footnotetext{
40 Morgenthau H, Politics among nations, 71.

41 Hobson J A, Imperialism: A study, George Allen \& Unwin Ltd, 1903, 12.

42 Hobson J A, Imperialism: $A$ study, 41.

43 Woolf L, Empire and commerce in Africa: A study in economic imperialism, George Allen \& Unwin Ltd, 1968.

44 Hobson suggests that the economic condition is the taproot of imperialism. He explains that people would avoid imperialism were it not for the economic condition where countries constantly produce insufficient products in relation to the level of consumption and thus there is need to acquire more resources in order to increase production.

See Hobson J A, Imperialism: A study. Chapter VI, 71-92.

45 Lugard F, The rise of our East African Empire, William Blackwood \& Sons, Edinburgh, 1893, 379-382..

46 Schiller, H I, Communication and cultural domination, International Arts and Sciences Press, New York, 1976.
} 
ophy is injected into the minds of the people. It becomes so persuasive in their minds that it allows for the imperialist with a 'superior' culture or attractive political philosophy to garner the support and admiration of the people so that he can effectively take control of them. This form of imperialism appears legitimised since the minds of the people are such that they have consented to this rule and shifted their support from the existing rulers to the imperialists.

Cultural imperialism is often used concurrently with economic and military imperialism. Its role is to garner the support of the people using philosophies before employing military or economic imperialism forms. The effect is such that the ruled, and to an extent the rulers, become less opposed to other imperialistic tendencies. ${ }^{47}$

Despite sounding very abstract, this form of imperialism has had numerous successes. Two examples of such successes are the National Socialist philosophies of Germany before World War II and the Communist philosophies of the Soviet Union and China. The Nazi or National Socialist philosophies were particularly successful in Austria as can be evidenced by the invitation of Germany to occupy Austria in 1938 by the pro-National Socialist government. Most of Eastern Europe was loyal to the Soviet Union due to their subscription to the Communist policies. This was so much so that Russia gained immense control during the Cold Wars. ${ }^{48}$ These examples further show that cultural imperialism is often used to aid other forms of imperialism. Germany, for instance, used the National Socialist policy in order to gain support of the people to exact military control in Austria, which was instrumental to Hitler in World War II. The Soviet Union further used the Marxist and Leninist influence in Eastern Europe in order to gain support of the people allowing Russia to gain economic control of the Eastern European states.

In modern times, many authors have identified the media as a tool of cultural imperialism where the ownership, structure, distribution, or content of the media in any country are subjected to external pressures from the media interests of any other country or countries, without proportionate reciprocation of influence by the country so affected. ${ }^{49}$ Shriller further defines cultural imperialism as describing the situation where large multinational corporations, including the

47 Morgenthau H, Politics among nations, 72.

48 Morgenthau H, Politics among nations, 73.

49 Boyd-Barrett, JO, 'Media imperialism: Towards an international framework for an analysis of media systems', in eds Curran J, Gurevitch M, and Woollacott J, Mass communication and society, Edward Arnold, London, 1977, 116. 
media, of developed countries dominated developing countries..$^{50}$ Without assuming that the media is central to culture, ${ }^{51}$ the media does play an important role in the formation of culture. ${ }^{52}$

\section{Objectives of Imperialism}

Methods of imperialism are not to be confused with the objectives of imperialism. This means that despite military imperialism aiming to conquer militarily, economic imperialism aiming at economic exploitation, and cultural imperialism aiming at cultural displacement, all imperialistic tendencies or forms have one goal, which is to overthrow the status quo.

In line with the definition herein, the ultimate objective of imperialism is to change the relationship of power between the rulers and the ruled such that rule of the government of the day is replaced by the rule of the designer of imperialist policy.

\section{Terrorism}

\section{i. 'Terrorism' Defined}

In Kenya, the Prevention of Terrorism $\mathrm{Act}^{53}$ defines terrorism as:

'an activity carried out with the intent of 'intimidating or causing fear amongst members of the public or a section of the public,' 'intimidating or compelling the Government or international organisation to do, or refrain from any act,' or 'destabilizing the religious, political, constitutional, economic or social institutions of a country, or an international organization.'

However, no definition of terrorism has yet found universal acceptance. Several definitions have been offered, for instance by the UN General Assem$b^{5}{ }^{54}$, UN Security Council ${ }^{55}$, The UN Convention for the Suppression of the

\footnotetext{
50 Schiller H I, Communication and cultural domination, International Arts and Sciences Press, New York, 1976.

51 Tomlinson J, Cultural imperialism: A critical introduction, John Hopkins University Press, Baltimore, 1991.

52 White LA, 'Reconsidering cultural imperialism theory' Florida State University, 2000. http://tbsjournal.arabmediasociety.com/Archives/Spring01/white.html on 8 December 2015.

53 Article 2(b), Prevention of Terrorism Act (Kenya Gazette Supplement No. 149 of 2012).

54 UNGA, Measures to eliminate international terrorism, UN A/Res/49/60, 9 December 1994.

55 UNSC S/RES/1566 (2004) Concerning Threats to International Peace and Security Caused by Terrorism.
} 
Financing of Terrorism, ${ }^{56}$ the European Union, ${ }^{57}$ the United Kingdom, ${ }^{58}$ the United States, ${ }^{59}$ and the Arab Convention for the Suppression of Terrorism. ${ }^{60}$

The lack of a universally accepted definition of terrorism is itself inimical to the rule of law since it allows for politicised use of the law on terrorism, partial compliance with UN resolutions aimed at counter-terrorism and inconsistencies in counter-terrorism. ${ }^{61}$ Bassiouni, for instance, claims that the United States has consistently been opposed to a general definition of terrorism so that it can pick and choose the disparate norms that it wishes to rely upon and because it does not want to have an effective multilateral scheme that would presumably restrict its unfettered political power to act unilaterally. ${ }^{62}$

It is therefore important that we adopt a general definition of terrorism to streamline the fight against terrorism and thus ensure that states do not act in excess. This general definition of terrorism should be arrived at by compiling all the shared characteristics of terrorism as pointed out by states and international bodies in their own definitions. Despite the multiplicity and difference in the definitions offered above, all definitions seem to point to terrorism having four main characteristics: (1) the threat or use of violence; (2) a political objective, which is, the desire to change the status quo; (3) the intention to spread fear by committing spectacular public acts, and (4) the intentional targeting of civilians. ${ }^{63}$

\section{Terrorism as a form of Imperialism}

Based on the characteristics of terrorism, we see that terror attacks are designed or have a general aim to intimidate or compel the government or the population to adopt such conduct or action as will allow the terrorist to achieve his political or such other objective. Scholars have pointed to terrorism as politi-

56 Convention for the Suppression of the Financing of Terrorism, 9 December 1999, UN Doc 38349.http:// www.un.org/law/cod/finterr.htm on 23 Jan 2016.

57 Article 1, Council Framework Decision on Combating Terrorism, 13 June 2002, EU COE 2002/475/JHA.

58 Article 1, The Terrorism Act 2000).

59 Section 2331, U.S Federal Criminal Code, (US Chapter 113(B)), Chapter 9, 37, U.S. Army Field Manual, 14 June 2001, No. FM 3-0.

${ }^{60}$ Arab convention for the suppression of terrorism, 1998.

${ }_{61}$ Peerenboom R, 'Human rights and rule of law: What's the relationship?' Research Paper No. 05-31. University of California, Los Angeles School of Law, Public Law \& Legal Theory Research Paper Series, 127

62 Bassiouni, MC, 'Legal control of international terrorism: A policy-oriented assessment', 43 Harvard International Law Journal, (2002), 83, 92.

63 Arizona Department of Emergencies and Military Affairs, Various Definitions of Terrorism. http://www.azdema.gov/museum/famousbattles/pdf/Terrorism\%20Definitions\%20072809.pdf on 23 January 2016. 
cal violence or the threat of violence by groups or individuals who deliberately target civilians or non-combatants in order to influence the actions or behaviours of targeted publics and governments. ${ }^{64}$

Such change in the conduct or action of government or population is indicative of the control newly acquired by the imperialist actor. The control of the government through terrorism is telling of a form of imperialism. This is because (in line with the definition given) the terrorist has managed to change the status quo by changing the relationship of power between the rulers and the ruled so that rule of the government of day is replaced by rule of the terrorist. Terrorism is thus similar to military, economic, and cultural imperialism since they share an objective.

As stated earlier, imperialism is classified into different forms by looking at the methods used in pursuit of imperialism, i.e. economic - economic exploitation, military- military conquest, cultural - cultural displacement. Terrorism should thus be classified as another type of imperialism due to the unique method used to achieve the imperialistic end.

Terrorism may appear to fall under military imperialism due to the use of actual force or violence to achieve its ends. This is not the case. Terrorism does not necessarily require violence to occur; the mere threat of violence is sufficient to classify it as a terrorist act. ${ }^{65}$ What defines terrorism is exactly that - 'terror.' Terrorists use fear to gain control.

Terrorists instil fear in the people such that they lose trust in the government of day to rule over them since they have been unable to protect them from those terrorist activities. As Nacos notes, central to terrorism is

the desire to intimidate a targeted population, to spread fear, and undermine the declared values of the targeted political system by pushing a frightened society and government into overreaction. ${ }^{.66}$

Terrorism is thus a different form of imperialism - Imperialism by Terror!

${ }^{64}$ Nacos B L, Terrorism and counterterrorism: Understanding threats and responses in the post-9/11 world, 2006, 32.

65 In Kenya, the crime is constituted without need to prove actual violence; mere threat is sufficient. Article 2(b), Prevention of Terrorism Act (2012).

66 Bridgette L. Nacos, 'Terrorism/counterterrorism and media in the age of global communication', United Nations University Global Seminar Second Shimame-Yamaguchi Session, "Terrorism-A Global Challenge", (5-8 August 2006), 6 .

http://archive.unu.edu/gs/files/2006/shimane/Nacos_text_en.pdf on 9 August 2015. 


\section{The Rule of Law}

The importance of the rule of law needs no further accentuation. Finnis, for instance, finds that the rule of law is 'the name commonly given to the state of affairs in which a legal system is legally in good shape ${ }^{367}$ whereas Raz contends that rule of law is a shorthand description of the positive aspects of any given political system. ${ }^{68}$ Importance can further be seen in the words of John Locke who states that 'Wherever the law ends, tyranny begins ${ }^{39}$

Difficulty has, however, been found in describing this concept of the rule of law. While discussing the subject of the rule of law, one would certainly be remiss if he failed to mention Dicey and his conception of the rule of law. ${ }^{70} \mathrm{He}$ argued that the rule of law had three conceptions: 1) no man can be lawfully punished except for a distinct breach of law established in the ordinary legal manner before the ordinary courts of the land; 2) every man, whatever be his rank or condition, is subject to the ordinary law of the realm and amenable to the jurisdiction of the ordinary tribunals; 3 ) rights such as the right to personal liberty, freedom from arrest etc. are drawn from judicial decisions in England rather than from constitutions. ${ }^{71}$

This paper will focus on the eight precepts of the rule of law as offered by Lord Tom Bingham. ${ }^{72}$ His rule of law precepts shall form the foundation for analysis of measures taken in dealing with terrorism to determine whether they have respected or violated the rule of law. He identifies the fundamental precepts of the rule of law as follows:

'1) The law must be accessible and intelligible; 2) disputes must be solved by application of the law rather than the exercise of discretion; 3) the law must apply equally to all; 4) the law must protect fundamental human rights; 5) disputes must be solved without prohibitive cost or inordinate delay; 6) public officials must use power reasonably and not exceed their powers; 7) the system for resolving differences must be fair and; 8) a state must comply with its international law obligations. ${ }^{73}$

\footnotetext{
Finnis J, Natural law and natural rights, Oxford, 1980, 270.

68 Raz J, 'The rule of law and its virtue' in The Authority of Law: Essays on Law and Morality, Oxford, $1979,210$.

69 Locke J, Second treatise of Government, 1690, Chap XVII, s.202, Cambridge, 1988, 400.

See also Paine T, Common sense, London, 1994, 279.

70 Dicey A V, An introduction to the study of the law of the constitution, London, 1885

71 Dicey A V, An introduction to the study of the law of the constitution, Part II.

72 Bingham T, 'The Rule of Law', 66 Cambridge Law Journal 67, 2007, 69.

73 Bingham T, 'The Rule of Law', 69. See also Wagstaff R, Terror Detentions and the Rule of Law: US and UK perspectives, Oxford University Press, 2014, 115.
} 
As Ambani argues, it is not difficult to identify traces of the rule of law in the Constitution of Kenya, 2010. ${ }^{74}$ True to this, Bingham's precepts of the rule of law can be identified in constitutional provisions. To begin with, ours is a written constitution. Some argue that this will enable closer regulation of political action because it prescribes more fundamental functions of government than an unwritten constitution would. ${ }^{75}$ This is in line with Bingham's first precept since a written constitution is more accessible and intelligible than an unwritten one.

The second precept is seen through the provision that every person has the right to have any dispute that can be resolved by application of the law decided in a fair and public hearing before a court. ${ }^{76}$

Article 2 resonates with Bingham's third precept in its provision that 'this constitution is the supreme law of the Republic and binds all persons and all state organs at both levels of government. ${ }^{97}$ The fourth precept is further satisfied by the provisions in the Bill of Rights, which guarantee protection of life, equality, human dignity, freedom of expression, freedom from discrimination and other essential rights. ${ }^{78}$

In line with the fifth precept, Article 50 protects the right of the accused to have the trial begin and conclude without unreasonable delay. ${ }^{79}$ The Constitution also complies with Bingham's sixth precept since according to Article 2, 'no person may claim or exercise state authority except as authorised under this Constitution. ${ }^{80}$ This provision enables the constitution to check the powers of state authorities. The Constitution also promotes accountability of authorities through its national values and principles of good governance, integrity, transparency and accountability. ${ }^{81}$

All accused persons are further afforded the right to fair trial ${ }^{82}$ in line with the seventh precept. The eighth precept is also complied with through Article 2(5), which provides that the general rules of international law shall form part of the laws of Kenya. Article 2(6) is additional proof of Kenya's intention to obey its international law obligations; it states that 'any treaty or convention ratified by Kenya shall form part of the law of Kenya under this Constitution. ${ }^{83}$

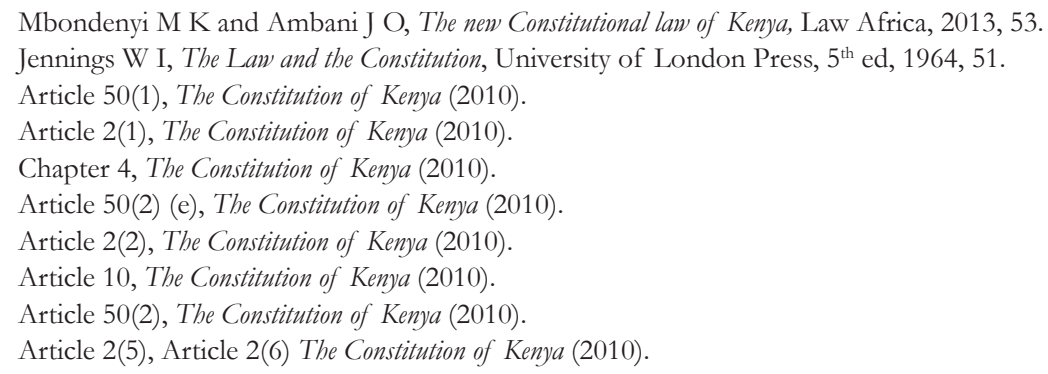


The fact that the constitution provides for and affirms the rule of law should be taken in consideration since it is the supreme law. No deviations and inconsistencies with the Constitution, including the rule of law precepts, are allowed even when provided in other laws or practices. ${ }^{84}$ In the words of Lord Bingham:

'The statutory affirmation of the rule of law as an existing Constitutional principle and of the Lord Chancellor's existing role in relation to it does have an important consequence: that the judges, in their role as journeymen and judgment-makers, are not free to dismiss the rule of law as meaningless verbiage, the jurisprudential equivalent of motherhood and apple pie, even if they were inclined to do so. They would be bound to construe a statute so that it did not infringe an existing Constitutional principle, if it were reasonably possible to do so. And the Lord Chancellor's conduct in relation to that principle would no doubt be susceptible, in principle, to judicial review. ${ }^{95}$

\section{Terrorism and the Rule of Law}

Some argue that those who insist on the importance against the law in the fight for terrorism are at best naïve. ${ }^{86}$ To be clear, arguments on the rule of law are indeed powerless to prevent terrorism. No law can single-handedly curb terrorist activity. Laws can make terrorist action difficult, for instance, by freezing the accounts of suspected terrorists. However, they cannot completely deter a terrorist from engaging in terrorist activity. ${ }^{87}$ What, then, is the importance of the rule of law?

The importance of this section is not to romanticise the rule of law but rather to show the benefits of observance of the rule of law. This section attempts to prove that respect for the rule of law is instrumental to Kenya achieving its goal, which in this case is to win the fight against terrorism.

First, respect for the rule of law is essential in order to preserve the democracy that is Kenya. Democracy, rule of law and individual freedoms are closely interlinked. Without individual freedom and the rule of law, real democracy cannot exist. ${ }^{88}$ The Kenyan Constitution provides for the Bill of Rights, which enshrines some of the fundamental rights that must be respected. ${ }^{89}$ Actions that are

\footnotetext{
84 Article 2(4), The Constitution of Kenya (2010).

85 Bingham 'T, 'The Rule of Law', 69.

86 Wedgwood R, 'The case for military tribunals', Wall Street Journal, 3 December 2001, A18.

87 Peerenboom R, 'Human Rights and rule of law', 128.

88 Hostettler P, 'Human Rights and the war against international terrorism' in Terrorism and International Law: Challenges and Responses, ed Schmitt M and Beruto G L, 2002, 30-39.

89 Chapter 4, The Constitution of Kenya (2010).
} 
in violation of people's rights place in jeopardy core procedural rights guaranteed by the Constitution and fundamental principles. ${ }^{90}$

In order to combat terrorism, the government and its security forces need to be perceived as complying with the rule of law; fair procedures are important if the aim is to deter future acts of terrorism or at least to not inspire new ones. ${ }^{91}$ When states violate human rights they surrender the moral high ground and their constitutional legal foundation; the human rights violations can be used by the media to demonstrate the ruthlessness of a government, which may in turn increase the number of direct or indirect supporters of terrorist organisations. ${ }^{92}$

Upholding existing norms regarding due process and civil liberties, even during a time of crisis, will demonstrate commitment to rule of law, serve an educative function in isolating terrorists and distinguish their unjust means from our just and venerable methods, while promoting the development of laws and norms regarding terrorism. ${ }^{93}$ As was expressed by J. O'Connor in Hamdi v Rumsfield, it is during the most challenging and uncertain moments that a nation's commitment to due process is most severely tested; and it is in those times that we must preserve our commitment. ${ }^{94}$

Moreover, it is argued that counter-terrorism laws that threaten fundamental rights are likely to result in state terrorism ${ }^{95}$ in the form of police violence, torture, sexual assault, and illegal arrest and detention based on ethnicity, race, religion or class background. ${ }^{96}$

Finally, counter-terrorism methods that violate the rule of law are likely to result in more violence. ${ }^{97}$ In the words of Farer,

90 'To those who scare peace-loving people with phantoms of lost liberty; my message is this: Your tactics only aid terrorists—-for they erode our national unity and diminish our resolve.'

Attorney General John Ashcroft 'Preserving Our Freedoms While Defending against Terrorism' Hearing before the senate committee on the Judiciary, 107th Congress, 2001. http://www.senate. gov/ judiciary/print_testimony.cfm?id=121\&wit_id=42 on 8 December 2015.

Dickinson L A, 'Using legal process to fight terrorism', 1477.

92 Hostettler P, 'Human Rights and the war against international terrorism.'

93 Peerenboom R, 'Human rights and rule of law', 1435-67.

94 Handi v. Rumsfeld, 124 S. Ct. 2633, 2648 (2004) (O’Connor, J.).

95 State terrorism refers to acts or threats to violence, by a state, towards foreigners or towards its own people that would ordinarily constitute terrorism.

See Primoratz I, 'State terrorism and counter-terrorism' Centre for Applied Philosopby and Public Etbics, Working Paper Number 2002/3, 2002, 1-3.

96 Head M, 'Counter-terrorism Laws Threaten Fundamental Democratic Rights' 27(3) Alternative Law Journal, 2002, 125.

See also McCulloch J, 'War at Home: National Security Arrangements Post 11 September 2001’27(2) Alternative Law Journal, 2002, 90.

97 Quoting John F. Kennedy, 'Those who make peaceful evolution impossible, make violent revolution inevitable.' Bassiouni, M C, 'Legal Control of International Terrorism', 103. 
"Once the frame of order is broken, we can reasonably anticipate increasingly normless violence, pitiless blows followed by monstrous retaliation in a descending spiral of hardly imaginable depths." ${ }^{\circ 8}$

\section{Measures taken to curb Terrorism within Kenya's borders ${ }^{99}$}

\section{i. $\quad$ The Anti-terrorism Police Unit (ATPU)}

To handle terrorist threats, a Special Branch of the police known as the Anti-terrorism Police Unit (ATPU) was created within the Criminal Investigations Department (CID) in 2003. ${ }^{100}$ The ATPU is funded by the United States of America and the United Kingdom with the United States being rumoured to have funded $\$ 9$ million $^{101}$ (or is it $\$ 19$ million? ${ }^{102}$ ) in Anti-terrorism assistance to Kenya in 2012 alone, part of which went to training officers of the ATPU. The ATPU has been credited with thwarting dozens of other terrorist plots, the capture of several terrorist suspects and the arrest or killing of dozens of terrorist suspects, in an ostensibly robust counterterrorism response. ${ }^{103}$

The ATPU has, however, been criticised for violations of several human rights abuses. Several human rights activists have accused the ATPU of using counter-terrorism measures to persecute the Kenyan Muslim community. ${ }^{104}$ The ATPU has been accused of repeatedly acting against the rule of law. These accusations include:

98 Farer T J, 'Beyond the Charter frame: Unilateralism or condominium', 96 American Journal of International Law (2002), 386.

99 The focus here shall only be on the government's measures taken within Kenya. This means that this paper will not look into the actions of the Kenyan Government and military forces in Somalia including any operations conducted by the KDF in conjunction with or as part of the AMISOM mission in Somalia. Though such analysis should indeed be understood, it would be of little relevance to the findings of this paper.

100 Kenya: Killings, disappearances by Anti-Terror Police', 18 August 2014. https://www.hrw.org/ news/2014/08/18/kenya-killings-disappearances-anti-terror-police on 25 July 2015.

This was in response to the attacks on the US embassy in Nairobi in 1998 and on an Israeli-owned Mombasa hotel in 2002.

101 Kenya: Killings, disappearances by Anti-Terror Police', 18 August 2014.

102 'Kenya anti-terror police accused of killing suspects' 18 August 2014. http://www.nation.co.ke/ news/Human-Rights-Watch-ATPU-killings-al-shabaab-terrorism/-/1056/2422670/-/jtq6y3z/-/ index.html on 21 July 2015.

103 See MUHURI and Open Society Justice Initiative, We're tired of taking you to the Court: Human rights abuses by Kenya's Anti-Terrorism Police Unit, Open Society Foundations, New York, 2013. https://www. opensocietyfoundations.org/sites/default/files/human-rights-abuses-by-kenya-atpu-20140220.pdf on 25 July 2015.

104 Ploch L, Countering Terrorism in East Africa: The U. S. response, Congressional Research Service, 13 November 2010, 37. See also, U. S Department of State, International Freedom Report 2009, 6 October 2009. 


\section{ii. Arbitrary Arrest and Detention}

The ATPU has conducted several raid and arrest operations where they have arbitrarily detained suspects. For instance, in 2012, the ATPU allegedly conducted such an operation in Mombasa on November $13^{\text {th }}$ and $14^{\text {th }}$ when they arrested and detained at least 9 individuals. ${ }^{105}$ Several such detentions have been cited by the NGO, Muslims for Human Rights (MUHURI). ${ }^{106}$

\section{iii. Extra-judicial Killings or Assassinations}

The ATPU has further been accused of assassinations of terrorist suspects such as Kassim Omollo, ${ }^{107}$ Kassim Mohammed Nero, ${ }^{108}$ Omar Faraj and Titus Nabiswa. ${ }^{109}$ It is also suspected that they played a part in the killings of Sheikh Ibrahim Omar Rogo, Sheikh Aboud Rogo, ${ }^{110}$ and Samir Hashim Khan. ${ }^{111}$

\section{iv. Extraordinary Renditions}

The ATPU has been accused of unlawfully transferring suspects to Ethiopia, Uganda, Somalia and the United States. ${ }^{112}$ In 2007, Kenya reportedly ren-

105 'Kenyan police arrests five more terror suspects in Mombasa' Xinbua, 15 November 2012. http:// www.shanghaidaily.com/Article/Article_xinhua.asp?id=107845 on 24 July 2015. See also 'Rogo's children arrested in raid', Daily Nation, 14 November 2012. http://www.nation.co.ke/News/Rogoschildren-arrested-in-raid/-/1056/1619702/-/qjv816z/-/index.html on 23 July 2015.

106 MUHURI, We're tired of taking you to the Court, 26-34.

107 'Terror suspect gunned down in Mombasa', The Nairobi Star, 17 June 2013. http://www.the-star. co.ke/news/Article-124521/terror-suspect-gunned-down-mombasa on 25 $5^{\text {th }}$ July 2015.

108 'Kenya: Terror Suspect Gunned Down in Mombasa', The Nairobi Star, 17 June 2013. http:// allafrica.com/stories $/ 201306170999 . h t m l$ ?utm_source=feedburner\&utm_medium =feed\&utm_ campaign $=-$ Feed $\% 3 \mathrm{~A}+$ AllafricaNewsKenya $+\% 28$ News\%3A+Kenya\%29 on 23 July 2015.

See also, 'Kenya: Wives of slain terror suspects charged in Mombasa, Kilifi' Star, 18 June 2013. http:/ / allafrica.com/stories/201306181662.html on 28 July 2015.

See also, 'Mombasa police arrest wife of killed terror suspect,' Coast Week, June 14-20, 2013. http:/ / www.coastweek.com/3624-mombasa-terror-suspect-arrested.htm on 28 July 2015.

109 'Terror suspects killed in Mombasa', The Nairobi Star, 16 November 2012.

110 'Aboud Rogo, Kenya Muslim cleric, shot dead', Associated Press, 27 August 2012. See also Horowitz J, 'Assassinations, disappearances, and riots: What's happening in Mombasa?' Open Society Justice Initiative, August 29 2012, www.soros.org/voices/assassinations-disappearances-and-riots-what-shappening-mombasa on 27 July 2015. See Task Force on the Investigation into the murder of Aboud Rogo Mohammed, No. 16300 (2012), Kenya Gazette Vol CXIV—No 111, http://www.kenyalaw.org/ klr/index.php?id=1157 on 27 July 2015.

See Multi-Agency Task Force on the murder of Aboud Rogo Mohammed and other criminal acts that followed the murder of Aboud Rogo Mohammed, Report on the Murder of Aboud Rogo Mohammed and Other Acts of Criminalities, August 2013 1-5, 167.

111 Human Rights Watch, 'Kenya: Set Independent inquiry on Mombasa killing: Police must continue to comply with law responding to unrest', Press Release, August 28, 2012. http://www.hrw.org/ news/2012/08/28/kenya-set-independent-inquiry-mombasa-killing, on 27 July 2015.

112 Amnesty International, Kenya: Unlanful transfer of 'terror suspects' must be investigated. 31 July 2008. 
dered 85 terrorist suspects to Somalia who were thereafter rendered to Ethiopia. ${ }^{113}$ The ATPU in Mombasa was further reported to have arrested terror suspect, Mohammed Abdulmalik, and transferring him to US personnel who later rendered him to Djibouti, where he was detained in a US military base and thereafter rendered to Afghanistan and moved to his current detention at Guantanamo Bay. ${ }^{114}$

\section{v. Excessive Use of Force and Torture}

Several reports of terrorist suspects being beaten and subjected to forms of violence. In the Northern, North Eastern, and Coastal regions, which have large populations of Somalis and Muslims, the ATPU has been reported to injure several while rounding up 'terrorist suspects.'115

The ATPU has aslo been accused of actions that amount to torture. The ATPU is accused of using torture and other prohibited means of investigation to extract information from terror suspects. It has further been accused of rendering suspects to jurisdictions where they face a real risk of torture. ${ }^{116}$

\section{vi. Disappearances}

The ATPU has further been accused of being responsible for the disappearance of terror suspects. Several reports indicate that before the suspects disappeared, they had encountered the police. ${ }^{117}$ Such instances include the

113 Muslim Human Rights Forum, Horn of Terror: Report of US-led mass extra-ordinary renditions from Kenya to Somalia, Ethiopia, and Guantanamo Bay, January-June 2007: Presented to the Kenya National Commission on Human Rights on 6 July 2007. See also, Human Rights Watch, 'Ethiopia/Kenya: Account for Missing Rendition Victims: Secret Detainees Interrogated by US Officials Are Still in Custody', Press Release, 1 October 2008. http://www.hrw.org/news/2008/10/01/ethiopiakenyaaccount-missing-rendition-victims on 27 July 2015.

114 Reprieve, Mohamed Abdulmalik, (prisoner profile), at www.reprieve.org.uk/mohammedabdulmalik.

115 Human Rights Watch, 'Criminal Reprisals: Kenyan Police and Military Abuses against Ethnic Somalis', May 2012. www.hrw.org/sites/default/files/reports/kenya0512webwcover.pdf on 27 July 2015. See also Human Rights Watch, 'Kenya: End Police Reprisals in Northern Region: Police Abuse Villagers after Attacks on Security Forces', Press Release, 25 October 2012. http:/ www.hrw.org/ news/2012/10/25/kenya-end-police-reprisals-northern-region on 28 July 2015.

116 Open Society Justice Initiative, Counterterrorism and Human Rights Abuses in Kenya and Uganda: The World Cup bombing and beyond, November 2012.

See also Muslim Human Rights Forum, Horn of Terror: Report of US-led Mass Extra-ordinary Renditions from Kenya to Somalia, Ethiopia, and Guantanamo Bay, January-June 2007.

117 Human Rights Council, Working Group on Enforced or Involuntary Disappearances, Ninety-ninth session postsessional document, A/HRC/WGEID/99/1, March 11-15, 2013, para. 16. 
disappearance of Badru Mramba, ${ }^{118}$ Sylvester Owino Opiyo, and Jacob Musyoka. ${ }^{119}$

\section{Vii. The Prevention of Terrorism Act (2012)}

In its attempts to fight terrorism, Kenya has enacted a law specific to terrorism. Hon. Mwai Kibaki signed the Prevention of Terrorism Act into law in October 2012. ${ }^{120}$ Kenya had been under pressure from foreign governments to make a law specific to terrorism. ${ }^{121}$

Critics have warned and argued against this law for the following reasons:

\section{viii. Limitation of Fundamental Rights}

It is argued that Section 35 can be misused by authorities to deny fundamental rights as it allows for limitations on specified fundamental rights for the purposes of investigating, detecting, or preventing terrorist acts, and to balance opposing fundamental rights. ${ }^{122}$

\section{ix. Vague Provisions}

The very definition of terrorism in the Act is vague. ${ }^{123}$ Additionally, Section 2(a) criminalises acts that create a "serious risk to the health or safety of the public", "result in serious damage to property", or that "prejudices national security or public safety". It does not, however, offer explanations on what may constitute such actions.

18 MUHURI, Interview with male witness, Mombasa, 138.

MUHURI, Interview with Rehema Lugogo, November 17, 2012, Mombasa.

https://www.opensocietyfoundations.org/sites/default/files/human-rights-abuses-by-kenyaatpu-20140220.pdf on 28 July 2015.

119 'Lawyers suspect Kenyan police in terror abduction', Associated Press, 26 May 2012. http:/ / bigstory. ap.org/content/lawyers-suspect-kenyan-police-terror-abduction on 27 July 2015.

120 'Kibaki signs historic Anti- terrorism Bill', Standard Digital, 14 October 2012. http://www. standardmedia.co.ke/?ArticleID=2000068354\&pageNo=2\&story_title on 27 July 2015.

121 U.S. Department of State Bureau of Counterterrorism, Country Reports on Terrorism 2011, July 2011, 17. www.state.gov/documents/organization/195768.pdf on 25 July 2015.

122 This is subject to the Article 24 derogation clause of the Constitution.

See Article 35, Prevention of Terrorism Act, 2012.

123 Section 2(b), The Prevention of Terrorism Act, 2012.

See argument in the 'terrorism' defined' section of the paper. 
Section 37(2) is also unclear as it exempts the Inspector-General from applying for an exparte order from a judge for the police to seize property when "it is not reasonably practicable, having regard to the urgency of the situation" so long as he notifies a judge within 72 hours. There is, however, no provision that assists in the determination of an urgent situation.

Moreover, the Inspector-General of Police is empowered under Section 3(1) (b) (iii) where reasonable grounds exist, to recommend that the cabinet secretary declare a person, group, or trust a terrorist group and subject it to various sanctions. Such a label can easily be given as long as the entity acts "in association with" another designated entity. However, a description of what would be constituted as done 'in association with' a designated entity is lacking.

\section{x. Violation of Freedom of Association and Assembly}

Section 24 provides for criminal action against the members of a group that has been designated as terrorist so long as the group has received such designation. This section does not require that the individuals engage in terrorist act themselves but rather criminalises such individual for merely being involved with the group.

Section 25 further criminalizes the organization, facilitation, or assistance in organizing or facilitating a meeting where an individual knows or has reason to believe the meeting's purpose is to support the terrorism group or further the activities of the terrorism group. This provision fails to recognise the fact that a grouping designated as terrorist may not be carrying on a meeting for a criminal purpose and thus risks punishing people for playing a role in organising a meeting that was not criminal.

Neither of these provisions necessitates that the requirements of Article 24 of the Constitution, read together with Article 22 of the International Covenant on Civil and Political Rights (ICCPR) ${ }^{124}$ and Article 11 of the African Charter on Human People's Rights (ACHPR), ${ }^{125}$ be proved. These provisions require that limitations on fundamental rights be allowable only when provided by law, justifiable in a democratic society and when they serve a legitimate aim.

\footnotetext{
124 On restrictions of the right to freedom of association. Article 22, International Covenant on Civil and Political Rights, 999 U.N.T.S. 171, 6 I.L.M. 368.

125 On restrictions of the right to freedom of assembly. Article 11, African Charter on Human and Peoples' Rights, 1520 U.N.T.S. 217.
} 


\section{xi. Protection of the Rights of Arrested Persons and Detainees}

Section 32(10) of the Act, however, conflicts with Article 49 and $50^{126}$ of the Constitution. It empowers a court to extend an individual's detention in police custody for purposes of investigation for up to 30 days upon an application from the police, and that a judge can continue to extend the detention for a further period of up to a total of 90 days.

Section 33 of the Act requires that before the application described by the provision of 32(10) is granted, the police officer must specify the offense and describe the evidence available. This further allows the individual to be detained for longer periods pending the investigation. This leads to detention that is unlawfully prolonged.

The right to fair administrative action as protected by the Bill of Rights in Article 47 of the Constitution is further at risk of violation due to section 3 of the Act, which provides for designation as a terrorist. This section allows the Cabinet Secretary, upon recommendation by the Inspector-General, to designate a person, group or trust as a terrorist group and subject it to various sanctions where 'reasonable grounds exist.' This lowers the threshold for criminal offences, which is 'beyond reasonable doubt.'127

Section 3(7) of the Act, which provides that the High Court may also exclude the applicant and his or her counsel from accessing evidence upon which the court relies, further violates the right to a fair hearing. This violates the requirement that the accused should have recourse to view the evidence brought upon him and to contest the allegations and evidence submitted by the prosecution. This further results in a denial of the accused person's right to respond.

Section 3(8) (a-b) of the Act allows the court to receive and consider any information it determines relevant. This provision does not prevent the government from presenting evidence obtained through torture or other interrogation means that are prohibited by international law. ${ }^{128}$

\footnotetext{
126 On the rights of arrested or detained persons.

127 Wilkinson S, 'Standards of Proof in International Humanitarian and Human Rights Fact-Finding and Inquiry Missions', Geneva Academy of International Humanitarian Law and Human Rights', 2011, 24. http://www.geneva-academy.ch/docs/Standards $\% 20$ of $\% 20$ proo $\% 20$ report.pdf on 27 July 2015 .

128 Article 15, Convention against Torture and Other Cruel, Inbuman or Degrading Treatment or Punishment, 1465 U.N.T.S. 85, 23 I.L.M 1027.
} 


\section{xii. Removal of the requirement to prove intent}

Section 46 empowers the Cabinet Secretary to refuse or revoke the registration of a company or association when they believe that such company or association has made available, or is likely to make available, directly or indirectly, any resources in support of a terrorist group. The absence of a requirement to show proof of wrongdoing enables the punishment of offenders despite such offenders not intentionally making available resources in support of a terrorist group.

The absence of an explicit requirement of the designated entity to have known it was committing, preparing, or attempting to commit a terrorist act or associating with a designated entity ${ }^{129}$ further risks abuse where a company or association may be designated as terrorist despite lacking such intent so long as it acted in association with a designated entity. Furthermore, there is no defence should the association prove lack of knowledge of the associated entity's designation as terrorist.

\section{xiii. The Security Laws (Amendment) Act}

On December 18 2014, Parliament had in a special sitting to deliberate on one of the more controversial bills tabled before it in recent years, ${ }^{130}$ the Security Laws (Amendment Bill). The President signed the bill into law days later, on December 19 2015. Several parts of the Bill (as it then was) were criticised. The process through which the bill was introduced was itself criticised for being hasty. ${ }^{131}$ The process was also against public participation since it was published on December 102014 and was not made immediately accessible before it was debated. ${ }^{132}$ According to reports, the speaker of the National Assembly, Justin Muturi, insisted that MPs vote and adopt the amendments on that day at all cost. ${ }^{133}$

\footnotetext{
Article 3, Prevention of Terrorism Act, 2012.

130 FIDH, 'Kenya: The Security Laws (Amendment) Act must be repealed', 19 December 2014. The debate created a rift between the Opposition Members of Parliament (MPs) and the Jubilee MPs. The speaker adjourned the debate twice and in the third sitting that afternoon, there was absolute chaos with MPs insulting and assaulting each other.

131 Human Rights Watch, 'Kenya: Security Bill tramples basic rights. Lawmakers should reject amendments', 13 December 2015.

132 Kenya National Commission on Human Rights, Advisory on The Security Laws (Amendment) Bill, 2014.

133 FIDH, 'Kenya: The Security Laws (Amendment) Act must be repealed’, 19 December 2014.
} 
xiv. Freedom of Expression and the Media

Clause 12 was in violation of Articles $33 \& 34$ of the Constitution. It penalized media coverage likely to incite violence, cause public alarm, and undermine investigations or security operations. The maximum sentence was three years in prison, a Kshs. 5 million fine or both. Clauses 15, 72 and 73 were in violation of Articles 34(2) and 35, which prohibit(s) state control of the media. It sought to amend the Penal Code to create the offence of publishing or causing to be published or distributed obscene, gory or offensive material likely to cause fear and alarm to the public or disturb public peace.

\section{xv. Arbitrary Detention}

Clause 18 (4) (c) and (10) violated Article 49 (g), and 25 (a) and (c) which provides for the right to be charged, not to be subjected to torture, cruel, inhuman or degrading treatment or punishment; and the right to a fair trial. The clauses made it possible for persons to be held without charge for a period of up to 90 days. This provision allows for detention without trial as a person is merely produced in court but not charged.

Clause 77 further removed the necessity of the police to inform the court why suspects are being held longer, from 90 days to 360 days.

\section{xvi. Fair Trial}

Clause 19 violates Article 49 (d), (f), (i), (j), (l) and Article 50 on the right to a fair trial. It enables the prosecution to withhold information and witnesses from an accused person and forces the accused person to incriminate himself or herself by sharing their information and witnesses.

\section{xvii. Right to Privacy}

Clause 66 eliminated the need for the National Intelligence Service (NIS) to seek a warrant from court meaning that the officers are able to carry out their functions without due regard to the law and respect for human rights, contrary to Article 238. It also suspends the role of the judiciary to ensure protection of privacy.

xviii. Security of Tenure and Independence of the National Security Organs

Clauses 63, 64 and 98 sought to remove the security of tenure of the Di- 
rector General of the National Intelligence Service and the Inspector General of the National Police Service. This violates Chapter 14 with the Executive suspending the powers of the people and Parliament that ensures accountability and oversight

\section{xix. Fair Administrative Action}

Clause 31 empowered the Director of Registration to take away citizenship rights through withdrawal of identity cards. It expands the grounds provided for under the Constitution by including a vague and indefinable ground 'any other justifiable cause. The person whose identity card has been revoked by the Director has no recourse for redress and this violates Article 47 to fair administrative action. This section would lead to discrimination.

\section{$x x$. The Courts}

The court's case law has been indicative of the desire to protect human rights even when dealing with terrorist suspects. The courts found that the ATPU's actions have amounted to torture through the unlawful detentions and renditions, ${ }^{134}$ and held the extraordinary renditions by the ATPU to be illegal. ${ }^{135}$

In Petition Nos 628 \& 630 of 2014(Consolidated), ${ }^{136}$ High Court Judge George Odunga ordered the suspension of eight clauses of the Security Laws (Amendment) Act because they were unconstitutional. He further urged that the provisions of Section $30 \mathrm{~A}$ and $30 \mathrm{~F}$ of the Prevention of Terrorism Act be interrogated before implementation because they may prima facie infringe upon the constitutional freedoms and fundamental rights. ${ }^{137}$

\section{xxi. Human Rights Legislations}

Kenya enacted the Constitution of Kenya 2010, the National Police Service $\mathrm{Act}^{138}$ and the Independent Policing Oversight Act. ${ }^{139}$ These new legislations

\footnotetext{
134 Salim Awadh Salim and 10 Others v. Commissioner of Police and three others, High Court at Nairobi, Petition No. 822 of 2008, 31 July 2013.

135 Zubura Suleiman v. Commissioner of Police and three others, High Court at Nairobi, Miscellaneous Application 441 of 2010, 30 September 2010.

Mohamed Aktar Kana v. Attorney General, High Court at Nairobi, Constitutional Application 544 of 2010.

136 Coalition for Reform and another $v$ Republic of Kenya and another [2015] eKLR.

137 Coalition for Reform and another $v$ Republic of Kenya and another [2015] eKLR, para 185.

138 National Police Service Act, (Act No. 11A of 2011).

139 Independent Policing Oversight, (Act No. 35 of 2011).
} 
have provisions meant to protect the human rights of people and to restrain the exercise of arbitrary powers by the police. The new Constitution provides for a Bill of Rights, which is meant to protect human rights. Criticism has, however, been levelled against the government since several violations have occurred even when these provisions have been in force.

\section{xxii. Oversight Authorities}

The creation of the National Police Service Commission, the Internal Affairs Unit, and the Independent Policing Oversight Authority are among the reforms taken which are capable of improving the situation. Through these and the enacted legislation, there are provisions for internal police accountability, independent oversight, police vetting and the compensation of victims of police abuses.

\section{Conclusion}

Viewed as a form of imperialism, it becomes clear that terrorism is not a novel problem. Terrorism has existed for long and manifestations of it through imperialism have been documented for time immemorial. Arguments that terrorism requires the suspension of normal rules are thus unfounded.

This paper has further shown the importance of the rule of law when dealing with terrorism. The rule of law serves the interests of the government. It is important to preserve the Kenyan democracy that is envisioned in the Constitution. Furthermore, respect for the rule of law is important in the fight against terrorism as it may delay violence and allow Kenya to gain support in the fight against terrorism since it shows there is respect for human rights. This goes a long way to end the menace through a joint effort to fight terrorism.

Kenya should thus refrain from such violations of the normal rules when dealing with terrorism. As it is, the Kenyan government has taken up questionable counter-terrorism measures. Some of the actions of its security agencies have been criticised by human rights' NGOs and the media worldwide. Some of the laws that Kenya has passed, in relation to terrorism, further allow for several violations of human rights and empower security agents to violate the rights of others without consequences. 
In the words of Madeleine Albright, former US Secretary of State,

'Terrorism is a criminal act and should be treated accordingly-and that means applying the rule of law fairly and consistently. We have found, through experience around the world, that the best way to defeat terrorist threats is to increase law enforcement capabilities while at the same time promoting democracy and human rights.... ${ }^{140}$

\section{Recommendations}

The Kenyan Government should strive to act within the bounds of the rule of law, and protect the rights of terrorist suspects, and convicted terrorists. Having identified the eight precepts of the rule of law as proposed by Bingham, recommendations to the Kenyan government should act in line with the provisions of these precepts.

\section{i. The Law Must Be Accessible and Intelligible}

The government should ensure that no laws in relation to terrorism are in conflict and these laws should not be in contravention with the Constitution. The government should remove the provisions of the Prevention of Terrorism Act that are found to contradict the Constitution. ${ }^{141}$ Contradiction in the laws does not allow for intelligibility. Otherwise one does not know what to expect from his actions.

\section{ii. Disputes Must Be Solved by Application of the Law Rather than Exercise of Discretion}

The government should ensure that the police and the ATPU do not carry out extrajudicial killings; torture and other ill-treatment; excessive use of force; disappearances; or other forms of arbitrary detention, renditions, and transfers to torture and other serious human rights violations.

The ATPU's conduct should be scrutinised by Independent Policing Oversight Authority (IPOA) and the National Police Service Commission (NPSC) to ensure that they act in compliance with the law and further ensure that any discretionary exercise of power is punished.

\footnotetext{
140 Secretary of State Madeleine Albright, Speech at University of World Economy and Diplomacy, Tashkent, Uzbekistan (April 17 2000). htttp://secretary.state.gov/www/statements/2000/000417. html. on 17 September 2015.

141 In line with Article 2(4), Constitution of Kenya, 2010.
} 


\section{iii. The law Must Apply Equally to All}

The Prevention of Terrorism Act and any other provision for handling terrorist suspects should not apply differently for citizens and aliens. Aliens should be allowed similar rights to citizens in the same position.

All terrorist suspects should be afforded the right to habeas corpus regardless of their origin.

The provision of Section 32 of the Prevention of Terrorism Act should be removed since it allows the police to hold terrorist suspects over long periods.

\section{iv. The Law Must Protect Fundamental Human Rights}

The ATPU should act in accordance with the human rights provided in the Bill of Rights as enshrined in the Constitution. In particular, they should not engage in actions such as unlawful killing and torture which are prohibited in the Constitution.

Independent investigations should be conducted into the accusations that ATPU members have played a role in extrajudicial killings, torture and other illtreatment. The ATPU should further be compelled to give such information as shall be required by the IPOA in carrying out investigations.

Parliament should enact laws that are explicit in the protection of human rights and that criminalize the contravention of human rights. This is in contrast to the Prevention of Terrorism Act, which did not explicitly prevent the government from adducing evidence obtained by torture.

The government should negotiate for the lawful return of terrorism suspects who have been rendered to other jurisdictions.

\section{v. Disputes Must Be Solved without Prohibitive Cost or Inordinate Delay}

The courts should not allow for the prolonged detention of terrorist suspects. Such detention costs the government a lot of money in the upkeep of prisoners, and further allows the suspects to be detained for long periods despite no evidence showing that they are guilty of the offences they are accused of. 


\section{vi. Public Officials Must Use Power Reasonably and Not Exceed their Powers}

The government should strengthen the Internal Affairs Unit, the NPSC and the IPOA to enable them ensure that the ATPU and other police officers act intra vires and without unnecessary discretion, and to account for their actions.

The DPP should bring criminal charges against ATPU officers should there be grounds to suspect that an officer committed a human rights abuse, including extrajudicial killings, torture and other ill-treatment, excessive use of force, and disappearances of persons as well as other forms of arbitrary detention, unlawful renditions, and transfers to locations where suspects will be tortured, or other serious human rights violations.

\section{vii. The System for Resolving Differences Must be Fair}

The courts should be fair and should waive provisions that allow the courts to forgo the terrorist suspect's right to a fair hearing. The prosecution and the terrorist suspect should have equal opportunities to state their case.

\section{viii. The State Must Comply with its International Law Obligations}

Parliament should ratify more international instruments that recognise and protect more human rights. For instance, Parliament should consider ratifying the International Convention for the Protection of All Persons from Enforced Disappearance and make the act of an "enforced disappearance" an offense under Kenyan criminal law. The Optional Protocol to the Convention against Torture and Other Cruel, Inhuman or Degrading Treatment and Punishment, which requires states' parties to set up, designate or maintain at the domestic level one or several visiting bodies for the prevention of torture and other cruel, inhuman or degrading forms of treatment or punishment.

Finally, it is critical that these laws be enforced. No change would result purely from well-written laws if these laws were not properly enforced. Enforcement requires respect for these laws by governments and individuals and, further, it requires the enforcement bodies and mechanisms to be checked and balanced. 